\title{
Frank M. Snowden, Epidemics and Society: From the Black Death to the Present
}

\author{
New Haven: Yale University Press, 2020. 608 pp. \$22.00. ISBN: 978-0300256390
}

\author{
Peter I. Rose ${ }^{1}$ \\ Published online: 20 July 2020 \\ (C) Springer Science+Business Media, LLC, part of Springer Nature 2020
}

"Everybody knows that pestilences have a way of recurring in the world; yet somehow we find it hard to believe in ones that crash down on our heads from a blue sky. There have been as many plagues as wars in our history; yet always plagues and wars take people equally by surprise." Those words of Albert Camus are uncannily timely.

In the late winter of 2020, the people of United States and those of many other countries around the world came to understand the significance of Camus' words as a rampaging respiratory virus brought everything to a standstill. Schools and universities closed, as did parks and services and most businesses. And, save for first responders, health professionals and those deemed essential workers - which included police, pharmacists, farm workers, grocers and garbage collectors, millions followed orders to shelter in place. Everywhere people began hunkering down, huddling around television sets, following round-the-clock cable newscasts and trying to come to grips with the daily reports of dramatic increases in the number of cases of those were ill and the numbers of those who had died.

Within three months the death toll had surpassed all who had perished in the First World War and all those who died in wars in which Americans had fought since the end of World War II. The direct and collateral effect of a form of a coronavirus that became known as Covid-19, including a precipitous plunge of the economy to depths not seen since the 1930s, was also felt everywhere.

What to do about all this was marked by a host of mixed signals from health authorities, economists, politicians and

Peter I. Rose

prosewriter@me.com

1 Sophia Smith Professor Emeritus of Sociology and Anthropology and Senior Fellow of the Kahn Liberal Arts Institute, Smith College, Northampton, Massachusetts, USA public officials, especially those in the highest reaches of governments. In this country, the president first denied that what had begun in China would reach our shores. Then, once he finally acknowledged that it did and was rapidly spreading, he set up a special task force to address it. But he constantly contradicted its recommendations about everything from social distancing, wearing masks, testing, and shutting down and when and how to open up again. With rates of infection continuing to rise and an increasing shortage of personal protective equipment and such appliances as ventilators to handle the onslaught, the epidemic soon became a political matter as much as a medical one.

While little consolation, in reports on cable news and in major newspapers, the public was repeatedly told that a pandemic such as this was not a new phenomenon. Commentators provided many examples; they often quoted Camus and cited the works of others.

Confinement and concern about the current outbreak caused some to turn from their watching and listening to reading or rereading Camus's The Plague (1947) and several other commentaries on raging pestilences from Samuel Pepys' The Great Plague of London (1665), and Daniel Defoe's A Journey of the Plague Year (1722), both accounts of the bubonic plague that devastated London in the middle of the seventeenth century to such modern depictions as the first story in Katherine Anne Porter's Pale Horse, Pale Rider (1939) about the Spanish influenza of 1918, the last to hit this country with the wallop of Covid-19.

In addition to such classics, booksellers reported an upsurge of sales of Michael Crichton's The Andromeda Strain (1969) and Gabriel Garcia Marquez' s Love in the Time of Cholera (1985). There was also an upsurge of interest in studies by investigative journalists and scholars, including The Coming Plague: Newly Emerging Diseases in a World Out of Balance (1994) by Laurie Garrett, Sheldon Watts's Ideology and Epidemics: Disease, Power and Imperialism 
(1999), Amanda Ripley's The Unthinkable: Who Survives When Disaster Strikes - and Why (2008), and Sonia Shah's Pandemic(2017).

Frank Snowden's new textbook, Epidemics and Society, should be added to this shelf of volumes on pernicious pestilences. Encyclopedic in scope, comprehensive in coverage, and highly readable, it provides a kind of course of study for anyone curious to learn more about the general subject. And that was the author's intent.

The book's genesis came about while Snowden, an emeritus professor of history at Yale, was preparing a syllabus for undergraduates on a subject rarely covered in such contexts or, for that matter, in medical schools or even in schools of public health. His goal in turning his lecture notes into a book, he said, "was not to reach specialists in the relevant fields, but rather to encourage discussion among general readers and students with an interest in epidemic diseases and a concern about or preparedness as a society to a new microbial challenges."

Beneath a cover aptly illustrated with a painting of the Grim Reaper scything the suffering multitudes, Snowden discusses the history, epidemiology, impact and consequences of epidemics. In its pages readers will find a wide range of facts and figures in the lessons the master teacher presents in the 22 chapters that comprise the bulk of a nearly 600-page tome, the last part of which includes quite a comprehensive bibliography of hundreds of books and articles on the general topic, on the sanitary movement, and on specific diseases and responses to them.

In addition to documenting the horrendous implications for the health and welfare of vast numbers of people in many eras and many different climes, what makes this book so unique and important to those in the social sciences is the ways in which each of the many epidemics Snowden cites represent a writlarge example of a social crisis and often a political one as well. Each disease discussed has resulted in some sort of societywide anomic situation. Each not only involved breakdowns in the normative order affecting all social institutions but responses to them often based on culturally specific ways of explaining their appearance, spread and often inexplicable causes. Not infrequently this meant placing the onus on nefarious forces, many best described as Satanic. These were often attributed to the Devil or to those seen as his agents, for example, the "perfidious" Jews in the Middle Ages. In recent centuries, the rogue elements and responsible parties for major diseases range from everything from ill-winds, poisons planted and distributed by enemy agents, filth and poverty, to various animal carriers like bats and a variety of micro-organisms.

Whoever or whatever is to blame, epidemics have inevitably resulted in significant changes in society that are reflected in the arts and literature, governments and their practices, and in the realms of science, technology, and in public health practices. Snowden's chronicle of the different diseases and his vivid descriptions of the often-dramatic changes in society related to them fit well into Norbert Elias' ideas about the evolution of social life, what he called "The Civilizing Process." Epidemics and Society also evokes the sort of Promethean arguments put forth in the Dutch sociologist Johan Goudsblom's writings on Fire and Civilization.

For example, the Black Death, a bubonic scourge that caused the demise of an estimated 20 million people, fully one-third of Europe's population, signaled the end of the Middle Ages and the beginning of a new era in human history. Out of the ashes of pyres that burned the corpses of those infected came new innovations as survivors sought to cope with what they had endured. As Elias would have put it, alongside the sudden eruption of viral diseases causing incalculable suffering, unfathomable numbers of deaths, despair and the total wreckage of social life as known prior to the onslaught, one could also see elements of ingenuity and imagination emerge.

These matters, too often neglected in historical portraits of such monumental tragedies, are well documented by Snowden and encapsulated in his words that, "Epidemics are not an esoteric subfield for the interested specialist but instead are a major part of the 'big picture' of historical change and development. [They are] as important to understanding societal development, as powerful forces in societal change as wars and revolutions."

Snowden's approach to describing all this is multi-leveled: each disease is placed in its broad historical, cultural and social context. The roles of faith, science and politics are considered and so are the lives and personalities of a number of key figures in the search for explanations and curatives from ancient times to this day. The professor explains how epidemics have almost always given rise to scapegoating, mass hysteria, and outbursts of religiosity and to novel responses in almost every sphere of life. He also indicates that while whole populations may find themselves caught up in the same storm, not all are in the same boat. Socio-economic factors and the relative statuses of various dominant and minority cohorts are extremely relevant to understanding the short and long-term effects of plagues.

We see this today in those ubiquitous graphs showing not only the rates of the disease but also the "cross-tabs" of its demographics indicating who is sick, who is dying, and who is recovering. What is particularly striking in the U.S. is the disproportionate impact of Covid-19 not only on the poor and elderly but on those in three minority cohorts: red, black, and brown Americans.

A quick perusal of the contents of Epidemics and Society indicates the richness of the text. Following an introduction on the general subject and a second chapter on "Humoral Medicine: the Legacy" which focused on the days of Hippocrates and responses to epidemics in ancient times, Snowden offers a discourse on the symptomology and pathology of various types of deadly plagues - bubonic, septicemic, 
pneumonic followed by a general chapter on "Responses to Plague." These give a foretaste of what he will subsequently discuss in far more focused and detailed cases studies. The first is the previously mentioned Black Death that occurred in Europe in the fourteenth century. He then considers many other epidemics, including other bubonic plagues, cholera, malaria, yellow fever, tuberculosis, paralytic poliomyelitis and the more recent outbreaks of MERS, HIV/AIDS, SARS and Ebola, whose flare-ups he refers to in the final chapter titled "Dress Rehearsals for the Twenty First Century." It was uncannily prescient.

In reference to the current plague, some epidemiologists are now saying that what started as an epidemic and turned into a pandemic may not go away. For various reasons COVID-19 or something like it could well become endemic and an increasing threat to all of Homo sapiens. It is something that the World Health Organization had also warned about as recently in a report with the sobering title, $A$ World at Risk. It was published in 2019 not long after the Trump Administration had all but cut the legs from under support for the organization and sharply curtailed the activities of those working with it as epidemiogists, biostatisticians and virologists prepared for another SARs- or MERs- or Ebolalike outbreak.

Snowden's own thoughts on this "future-is-now" matter appears not at the end but in the Preface to the new paperback edition of Epidemics and Society:
Like all pandemics, COVID-19 is not an accidental or random event. Epidemics afflict societies through the specific vulnerabilities people have created by their relationships with the environment, other species, and each other. Microbes that ignite the pandemic are those whose evolution has adapted them to fill the ecological niches that we have prepared. COVID-19 flared up and spread because it is suited to the society we have made. A world with nearly eight billion people, the majority of whom live in densely crowded cities and all linked by rapid air travel, creates innumerable opportunities for pulmonary viruses. At the same time, demographic increase and frenetic urbanization lead to the invasion and destruction of animal habitat, altering the relationship of humans to the animal world. Particularly relevant is the multiplication of contacts with bats, which are the natural reservoir of innumerable viruses capable of crossing the species barrier and spilling over to humans.

A sobering denouement and a frightening prospect. https://www.theprosewriter.com

Publisher's Note Springer Nature remains neutral with regard to jurisdictional claims in published maps and institutional affiliations.

Sociologist Peter Rose is a visiting scholar at the Institute for Research in the Social Sciences at Stanford University. His latest book is Tropes of Intolerance: Pride, Prejudice, and the Politics of Fear (Routledge, 2021). 